\title{
Publication Patterns of U.S. Academic Librarians from 1998 to 2002
}

\author{
Stephen E. Wiberley Jr., Julie M. Hurd, and Ann C. \\ Weller
}

This study examines the contributions of U.S. academic librarians to the peer-reviewed literature of library and information science (LIS). Compared to the authors' study of thirty-two journals for 1993-1997, the present study finds that for 1998-2002, there were declines in the total number of refereed articles (almost $4 \%$ ), number of refereed articles by academic librarians (almost 13\%), proportion of refereed articles by academic librarians (just over $4 \%$ ), proportion of academic librarian authors (almost $3 \%$ ), and proportion of coauthored articles by academic librarians (almost $4 \%$ ). Because different factors influence rates of authorship in a given set of journals and these rates tend to fluctuate in the short term, only further investigation can assess whether the declines are momentary or the start of a trend. Approximately 7 percent of academic librarians wrote three or more articles. The twenty most productive libraries published more than 10 percent of all refereed articles in the thirty-two journals and nearly one-third of the articles by academic librarians.

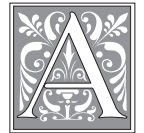

n important task for any discipline is to monitor the patterns of its publications. Members of a discipline need to know what different groups contribute to the field and the characteristics of its publications. Such knowledge locates, among other things, sources of strength in research and scholarship and the field's place among other disciplines. Proponents of the importance of the humanities have pointed to the need for developing data sets about publication trends in the humanities as one key indicator of the state of the humanities. ${ }^{1}$ For library and information science
(LIS), John M. Budd has twice followed up (once with Charles A. Seavey) on the work of Robert M. Hayes to provide analysis of data of scholarly productivity of faculty in graduate programs. ${ }^{2}$ In the present study, the authors replicate their 1999 investigation of publication patterns of U. S. academic librarians. ${ }^{3}$ In many ways, their study was a successor to investigations by Budd and Seavey (1990) and Paula D. Watson (1985). ${ }^{4}$ All three studies analyzed journals, the type of publication most favored by academic librarians. ${ }^{5}$

The present study asks the same questions the authors asked in 1999:

Stephen E. Wiberley Jr. is Professor and Bibliographer for the Social Sciences, Julie M. Hurd is Professor Emerita, and Ann C. Weller is Professor and Interim Director, Special Collections Department in the University Library at the University of Illinois at Chicago; e-mail: wiberley@uic.edu, jhurd@uic.edu, and acw@uic.edu, respectively. The authors thank Josephine Dorsch for reviewing a draft of this article. 
- Do academic librarians continue to provide a significant proportion of authors and articles in the peer-reviewed literature?

- What is the frequency of sole authorship and coauthorship for academic librarians?

- What kinds of libraries produce the most publications and have the most productive librarians?

- What has changed since 1997?

- What are the productivity benchmarks for practicing academic librarians? Productivity benchmarks especially must be updated to provide a credible context for librarians' performance evaluations, including promotion and tenure reviews.

Since 1999, there has been one broadly cast study of publication patterns in LIS-Budd's research on LIS faculty in degree-granting programs. Budd covered 1993-1996. He reported about the most productive individuals and programs, and showed that Research I Universities (now called Doctoral/Research Universities-Extensive) predominated among the most productive programs. ${ }^{6}$ Besides Budd's discipline-wide study, at least nine articles since 1999 have studied publication in LIS on a smaller scale, such as one or two journals, an individual institution, or a single state. ${ }^{7}$ Results reported in these articles provide a context for the findings of the present study. The present article discusses the relevant parts of these articles and older studies in relation to the results of the present investigation.

\section{Methodology}

The authors used essentially the same methodology they used in their 1999 article. The most difficult issue in both studies was selection of journals to analyze. For their 1999 study, the authors drew on expert opinion about the most important journals for academic librarians by turning to lists of journals used by Budd and Seavey's study of journal authorship that covered 1983 to 1987;
Mary T. Kim's comparison of perceptual and citation-based ranking of journals that used data from 1982 to 1984; and Barbara J. Via's survey of manuscript review of LIS journals that reports data from $1994 .{ }^{8}$ If at least two of these three lists included a journal, the 1999 article analyzed its publications. In all, thirtytwo journals were on at least two of the source lists and included peer-reviewed articles.

Analysis in the present study of the same journals investigated in 1999 has the advantage of providing a stable basis for comparison, but one that arguably does not capture present conditions as well as a different list would. An investigator could make plausible changes to the list. For example, because Canadian Journal of Library E Information Science, Information Processing and Management, and Journal of Information Science have no articles by U. S. academic librarians (table 1), one could argue they do not belong in a study of these academic librarians' publication patterns. Removing them from the list would, among other things, raise the percentage of articles by academic librarians. But removal also would lead to the well-founded concern that the change tells less about LIS as a whole and makes comparison with findings from 1999 less meaningful. A stable base is important for assessing the contribution of academic librarians to the literature of the field over time.

Instead of adding or subtracting journals to study, the authors decided to identify journals of comparable stature to those already on their list and include them in supplemental comparisons. The authors searched Ulrich's Periodicals Directory for refereed, U.S. LIS journals in the subject category "Library and Information Sciences" that had begun publication between 1982 and 1995 and a minimum of 400 holdings on WorldCat in July 2004. They chose 1982 as the earlier date because that encompassed the earliest date for data for the BuddSeavey and Kim studies. The authors 


\begin{tabular}{|c|c|c|}
\hline \multicolumn{3}{|c|}{$\begin{array}{l}\text { TABLE } 1 \\
\text { Academic Librarian Contributions to Refereed Articles in } \\
\text { Journals Studied, 1998-2002 }\end{array}$} \\
\hline Journal & $\begin{array}{l}\text { \% Academic } \\
\text { Librarian } \\
\text { Authors of } \\
\text { All Authors }\end{array}$ & $\begin{array}{l}\% \text { Refereed Articles } \\
\text { by One or More } \\
\text { Academic Librarians } \\
\text { of All Articles }\end{array}$ \\
\hline Technical Services Quarterly & $87 \%$ & $89 \%$ \\
\hline Research Strategies & $84 \%$ & $92 \%$ \\
\hline Reference Services Review & $82 \%$ & $89 \%$ \\
\hline Collection Management & $77 \%$ & $75 \%$ \\
\hline College \& Research Libraries & $77 \%$ & $84 \%$ \\
\hline Journal of Academic Librarianship & $70 \%$ & $71 \%$ \\
\hline Science \& Technology Libraries & $65 \%$ & $65 \%$ \\
\hline Library Resources \& Technical Services & $64 \%$ & $71 \%$ \\
\hline Behavioral and Social Sciences Librarian & $63 \%$ & $76 \%$ \\
\hline $\begin{array}{l}\text { Library Acquisitions: Practice and Theory/Library } \\
\text { Collections, Acquisitions, and Technical Services }\end{array}$ & $62 \%$ & $58 \%$ \\
\hline Information Technology \& Libraries & $61 \%$ & $69 \%$ \\
\hline Serials Librarian & $58 \%$ & $53 \%$ \\
\hline $\begin{array}{l}\text { Bulletin of the Medical Library Association/Journal } \\
\text { of the Medical Library Association }\end{array}$ & $55 \%$ & $67 \%$ \\
\hline Journal of Government Information & $55 \%$ & $63 \%$ \\
\hline Reference \& User Services Quarterly & $53 \%$ & $67 \%$ \\
\hline Notes: Music Library Association & $51 \%$ & $51 \%$ \\
\hline Resource Sharing and Information Networks & $50 \%$ & $48 \%$ \\
\hline Cataloging \& Classification Quarterly & $46 \%$ & $47 \%$ \\
\hline American Archivist & $39 \%$ & $36 \%$ \\
\hline Library Hi Tech & $39 \%$ & $41 \%$ \\
\hline Libraries \& Culture & $25 \%$ & $28 \%$ \\
\hline Online \& CD-ROM Review/Online Information Review & $23 \%$ & $21 \%$ \\
\hline Library Quarterly & $15 \%$ & $17 \%$ \\
\hline Library and Information Science Research & $9 \%$ & $13 \%$ \\
\hline Government Information Quarterly & $8 \%$ & $10 \%$ \\
\hline Public Libraries & $7 \%$ & $9 \%$ \\
\hline Knowledge Quest [formerly School Library Media Quarterly] & $4 \%$ & $6 \%$ \\
\hline $\begin{array}{l}\text { Journal of the American Society for Information } \\
\text { Science/Journal of the American Society for Information } \\
\text { Science and Technology }\end{array}$ & $2 \%$ & $4 \%$ \\
\hline Journal of Education for Library and Information Science & $1 \%$ & $2 \%$ \\
\hline Canadian Journal of Library and Information Science & $0 \%$ & $0 \%$ \\
\hline Information Processing and Management & $0 \%$ & $0 \%$ \\
\hline Journal of Information Science & $0 \%$ & $0 \%$ \\
\hline
\end{tabular}




\begin{tabular}{|l|c|c|}
\hline \multicolumn{3}{|c|}{ TABLE 2 } \\
Contributions of Academic Librarians to Journals Studied \\
\hline \hline & $\mathbf{1 9 9 3 - 1 9 9 7 *}$ & $\mathbf{1 9 9 8 - 2 0 0 2}$ \\
\hline Journals studied & 32 & 32 \\
\hline Issues in journals studied & 703 & 716 \\
\hline Issues/journal & 21.97 & 22.38 \\
\hline Refereed articles & 3,624 & 3,488 \\
\hline Refereed articles/issue & 5.16 & 4.87 \\
\hline Instances of authorship of refereed articles & 5,477 & 5,834 \\
\hline Authors per refereed article & 1.51 & 1.67 \\
\hline Refereed articles with at least one academic librarian author & 1,579 & 1,380 \\
\hline$\%$ refereed articles with at least one academic librarian author & $43.57 \%$ & $39.56 \%$ \\
\hline Instances of academic librarian authorship & 2,032 & 2,003 \\
\hline$\%$ instances of academic librarian authorship & $37.10 \%$ & $34.33 \%$ \\
\hline Academic librarian authors per article & 1.29 & 1.45 \\
\hline $\begin{array}{l}\text { Coauthored refereed articles with at least one academic librar- } \\
\text { ian author }\end{array}$ & 710 & 567 \\
\hline $\begin{array}{l}\text { \% coauthored refereed articles with at least one academic } \\
\text { librarian author }\end{array}$ & $44.97 \%$ & $41.09 \%$ \\
\hline Unique academic librarian names & 1,515 & 1,487 \\
\hline$\%$ unique academic librarian names & $74.56 \%$ & $74.24 \%$ \\
\hline Institutions & 386 & 379 \\
\hline *Data from Weller, Hurd, and Wiberley, "Publication Patterns of U.S. Academic Librarians \\
from 1993 to 1997," 356-57.
\end{tabular}

chose 1995 as the cutoff date because they thought that a journal needed at least three years to achieve the stature of the other journals in the present study, which covered 1998 to 2002. Moreover, they used 400 WorldCat holdings as their other criterion because the median holdings for all journals on the base list were 470 . Only two journals met these criteria and, upon further investigation, proved to be refereed: Journal of Interlibrary Loan, Document Delivery \& Information Supply (JILDDIS) and Medical Reference Services Quarterly.

Most of the present article reports results only for the original thirty-two journals. But on three key points - proportion of refereed articles written by academic librarians, proportion of academic librarian authors, and rates of coauthorship-the authors also report results for JILDDIS and Medical Reference Services Quarterly.

The authors followed the methodology of the previous study. First, they limited their analysis to refereed articles, using a strict definition that excluded articles from "theme" issues and symposium and conference proceedings unless other evidence showed such articles were refereed. Second, the authors recorded the same types of data as in 1999, including in their data set counts of all refereed articles in the journals studied, but detailed data only from articles that had at least one U.S. academic librarian author. As before, the authors relied on the institutional affiliation information given in the journal. The authors did attempt to reconcile variant forms of author and institutional names, but not name changes. ${ }^{9}$ 


\section{Results}

The 32 journals published 716 issues between 1998 and 2002. The investigators recorded data from all issues. The issues contained 3,488 peer-reviewed articles. Of these articles, 1,380 (39.56\%) were authored by at least one academic librarian. In total numbers, there were 5,834 instances of authorship and 2,003 $(34.33 \%)$ of these were academic librarians. Of these 2,003 instances, 1,487 (74.24\%) were unique academic librarian names (table 2).

Articles authored by academic librarians were not distributed equally among all the titles. Among the thirty-two LIS titles, the percentage of academic librarian authors from a U.S. institution ranged from 0 percent (Canadian Journal of Information and Library Science, Information Processing and Management, and Journal of Information Science) to 87 percent (Technical Services Quarterly). (See table 1.)

In the data set, the highest number of peer-reviewed articles for one author was ten (table 3). Academic librarians who published three or more articles during this time period comprised 7.40 percent of all those who published. Almost 80 percent of the academic librarians who published in these thirty-two journals were either a single author or a coauthor on only one publication during the fiveyear period studied.

Of the articles by academic librarians, $813(58.91 \%)$ were single-authored works (table 4). The remaining 567 articles (41.09\%) had two or more authors. Papers with three or more authors comprised 12.47 percent of the total.

Collaborations include both those with coauthors from other organizations and internal collaborations. Of the total 567 coauthored articles, 204 (35.98\%) documented collaborations across institutions (tables 2 and 5). (The total number of intra- and interinstitutional collaborations recorded in table 5 adds to more than 567 because some articles involved more than one type of collaboration.) The largest group of interinstitutional collaborations (128 articles, $62.75 \%$ ) represented col-

\begin{tabular}{|c|c|c|c|c|c|c|}
\hline \multicolumn{7}{|c|}{$\begin{array}{c}\text { TABLE } 3 \\
\text { Productivity of U.S. Academic Librarians from } 1993 \text { through } 2002\end{array}$} \\
\hline \multirow[t]{2}{*}{$\begin{array}{l}\text { \# of } \\
\text { Articles }\end{array}$} & \multicolumn{3}{|c|}{ 1993-1997* } & \multicolumn{3}{|c|}{ 1998-2002 } \\
\hline & $\begin{array}{c}\text { \# of } \\
\text { Authors }\end{array}$ & Percentage & $\begin{array}{l}\text { Cumulative } \\
\text { Percentage }\end{array}$ & $\begin{array}{c}\text { \# of } \\
\text { Authors }\end{array}$ & Percentage & $\begin{array}{l}\text { Cumulative } \\
\text { Percentage }\end{array}$ \\
\hline 10 & 1 & $0.07 \%$ & $0.07 \%$ & 1 & $0.07 \%$ & $0.07 \%$ \\
\hline 9 & 0 & $0.00 \%$ & $0.07 \%$ & 0 & $0.00 \%$ & $0.07 \%$ \\
\hline 8 & 2 & $0.13 \%$ & $0.20 \%$ & 0 & $0.00 \%$ & $0.07 \%$ \\
\hline 7 & 5 & $0.33 \%$ & $0.53 \%$ & 2 & $0.13 \%$ & $0.20 \%$ \\
\hline 6 & 2 & $0.13 \%$ & $0.66 \%$ & 5 & $0.34 \%$ & $0.54 \%$ \\
\hline 5 & 6 & $0.40 \%$ & $1.06 \%$ & 11 & $0.74 \%$ & $1.28 \%$ \\
\hline 4 & 26 & $1.72 \%$ & $2.78 \%$ & 22 & $1.48 \%$ & $2.76 \%$ \\
\hline 3 & 50 & $3.30 \%$ & $6.08 \%$ & 69 & $4.64 \%$ & $7.40 \%$ \\
\hline 2 & 236 & $15.58 \%$ & $21.66 \%$ & 222 & $14.93 \%$ & $22.33 \%$ \\
\hline 1 & 1,187 & $78.35 \%$ & $100.01 \%$ & 1,155 & $77.67 \%$ & $100.00 \%$ \\
\hline Total & 1,515 & & & 1,487 & & \\
\hline
\end{tabular}




\begin{tabular}{|c|c|c|c|c|c|c|}
\hline \multicolumn{7}{|c|}{$\begin{array}{c}\text { TABLE } 4 \\
\text { Coauthorship Patterns of U.S. Academic Librarians }\end{array}$} \\
\hline \multirow[t]{2}{*}{\begin{tabular}{c|} 
\# of \\
Authors
\end{tabular}} & \multicolumn{3}{|c|}{ 1993-1997* } & \multicolumn{3}{|c|}{ 1998-2002 } \\
\hline & $\begin{array}{c}\text { \# of } \\
\text { Articles }\end{array}$ & Percentage & $\begin{array}{l}\text { Cumulative } \\
\text { Percentage }\end{array}$ & $\begin{array}{c}\text { \# of } \\
\text { Articles }\end{array}$ & Percentage & $\begin{array}{l}\text { Cumulative } \\
\text { Percentage }\end{array}$ \\
\hline 1 & 869 & $55.03 \%$ & $55.03 \%$ & 813 & $58.91 \%$ & $58.91 \%$ \\
\hline 2 & 574 & $36.35 \%$ & $91.38 \%$ & 395 & $28.62 \%$ & $87.53 \%$ \\
\hline 3 & 94 & $5.95 \%$ & $97.33 \%$ & 114 & $8.26 \%$ & $95.79 \%$ \\
\hline 4 & 21 & $1.33 \%$ & $98.66 \%$ & 31 & $2.25 \%$ & $98.04 \%$ \\
\hline 5 & 15 & $0.95 \%$ & $99.61 \%$ & 13 & $0.94 \%$ & $98.98 \%$ \\
\hline 6 & 5 & $0.32 \%$ & $99.93 \%$ & 9 & $0.65 \%$ & $98.63 \%$ \\
\hline 7 & 1 & $0.06 \%$ & $99.99 \%$ & 3 & $0.22 \%$ & $99.85 \%$ \\
\hline 8 & 0 & $0.00 \%$ & $99.99 \%$ & 1 & $0.07 \%$ & $99.92 \%$ \\
\hline 9 & 0 & $0.00 \%$ & $99.99 \%$ & 0 & $0.07 \%$ & $99.92 \%$ \\
\hline 10 & 0 & $0.00 \%$ & $99.99 \%$ & 1 & $0.07 \%$ & $99.99 \%$ \\
\hline Total & 1,579 & & & 1,380 & & \\
\hline
\end{tabular}

laborations involving other librarians, principally academic librarians, but also public and special librarians. Forty-four articles $(21.57 \%)$ were coauthored with faculty members from other universities, with faculty in schools of LIS being most frequently involved.

Of the 380 intra-institutional collaborations, seventy-nine collaborators were from outside the library (fifty-four faculty, ten students, fifteen others; $20.79 \%$ ) (table 5). LIS and health sciences faculty were the most frequent collaborators, but some academic librarians published with faculty from various professional studies programs (business, education) and social sciences disciplines.

The data set was sorted by authors' institutional affiliation to produce a ranked list of the total author count per institution (table 6). All the twenty top-ranked institutions for 1998-2002 are members of the Association for Research Libraries (ARL), and by the Carnegie Classification of Institutions of Higher Education all are Doctoral/Research Universities-Extensive. ${ }^{10}$
Analysis of refereed articles in JILDDIS and Medical Reference Services Quarterly for 1998-2002 finds that academic librarians were authors of 125 of 180 (69.44\%) refereed articles, that academic librarians were 188 of $289(65.05 \%)$ of the authors of refereed articles, and that 49 of the 125 articles $(39.20 \%)$ were coauthored.

\section{Discussion}

The discussion covers the contribution of academic librarians to the refereed journal literature of LIS, patterns of coauthorship, and institutional leaders in refereed publications.

\section{Contribution of Academic Librarians to the Refereed LIS Journal Literature}

Table 2 shows that in the thirty-two journals analyzed by both the authors' 1999 study and the present one, the number of refereed articles declined from 3,624 in 1993-1997 to 3,488 in 1998-2002, a decrease of 3.75 percent. The number of refereed articles by at least one academic librarian author fell from 1,579 to 1,380 , a drop of 12.60 percent. Academic librar- 
ians authored or coauthored 39.56 percent of the peer-reviewed articles published between 1998 and 2002 in the thirty-two journals studied. This compares to 43.57 percent for 1993-1997, a decline of 4.01 percent. Instances of academic librarian authorship fell from 2,032 to 2,003 or from 37.10 to 34.33 percent of all authorship. If one factors in data from JILDDIS and Medical Reference Services Quarterly, the proportion of articles by academic librarians rises slightly to 41.03 percent and that of academic librarian authorship to 35.78 percent, both still below the percentages for 1993-1997.

The decline in the overall number of refereed articles, the fall in the number of refereed articles authored by academic librarians, the drop in the proportion of refereed articles by academic librarians, and the decrease in the percentage of authorship may derive from a number of sources. The discussion below considers four: change in the number of refereed LIS journals; potential number of authors; impact of individual journals; and fluctuations in publication patterns.

First, if there was growth in the number of LIS journals, the additional journals might have drawn articles away from older journals. If listings of journals in Ulrich's Periodicals Directory for the subject
"Library and Information Sciences" are any index, there was little growth in LIS journals between 1993 and 2002. During those years in the United States, nineteen peer-reviewed journals began publication and seventeen ceased publication for a net gain of two. Thus, for LIS journals there was almost a 1:1 ratio of new-to-ceased journals. If one presumes that an expanding field has a net growth in journals, LIS expanded little between 1993 and 2002.

Second, given that the number of LIS journals appears virtually unchanged from 1993 to 2002, the authors asked whether the number of academic librarians and other groups of potential authors may have changed. Data from the National Center for Education Statistics (NCES) show that the number of academic librarians increased. NCES's Academic Libraries and its predecessors reported 26,726 academic librarians and other professional staff in 1994, 27,268 in 1996, 30,041 in 1998, and 31,016 in 2000 (just over 16\% growth between 1994 and 2000). ${ }^{11}$ Also relevant are data on professional appointments in ARL libraries. Evidence reported by Mickey Zemon and Alice Harrison Bahr and by Kathleen Joswick suggests that librarians at larger libraries, especially research libraries, produce the majority of all publications

\begin{tabular}{|c|c|c|c|c|c|}
\hline \multicolumn{6}{|c|}{$\begin{array}{c}\text { TABLE } 5 \\
\text { Types of Collaborators }\end{array}$} \\
\hline \multirow[t]{2}{*}{ Collaborators } & \multicolumn{2}{|c|}{ Intrainstitutional } & \multicolumn{2}{|c|}{ Interinstitutional } & \multirow{2}{*}{$\begin{array}{c}\text { Total } \\
1998-2002\end{array}$} \\
\hline & $1993-1997 *$ & 1998-2002 & 1993-1997 & 1998-2002 & \\
\hline Academic librarians & Not available & 294 & 81 & 104 & 398 \\
\hline Faculty & 42 & 54 & 53 & 44 & 98 \\
\hline $\begin{array}{l}\text { Nonacademic } \\
\text { librarians }\end{array}$ & & & 23 & 24 & 24 \\
\hline Students & Not available & 10 & 4 & 6 & 16 \\
\hline Library support staff & Not available & 7 & 0 & 0 & 7 \\
\hline Other & Not available & 15 & 45 & 26 & 41 \\
\hline Total & & 380 & 206 & 204 & 584 \\
\hline \multicolumn{6}{|c|}{$\begin{array}{l}\text { *Data from Weller, Hurd, and Wiberley, "Publication Patterns of U.S. Academic Librar- } \\
\text { ians from } 1993 \text { to } 1997, \text {, } 357 . \\
\text { Some articles derive from more than one type of collaboration. }\end{array}$} \\
\hline
\end{tabular}




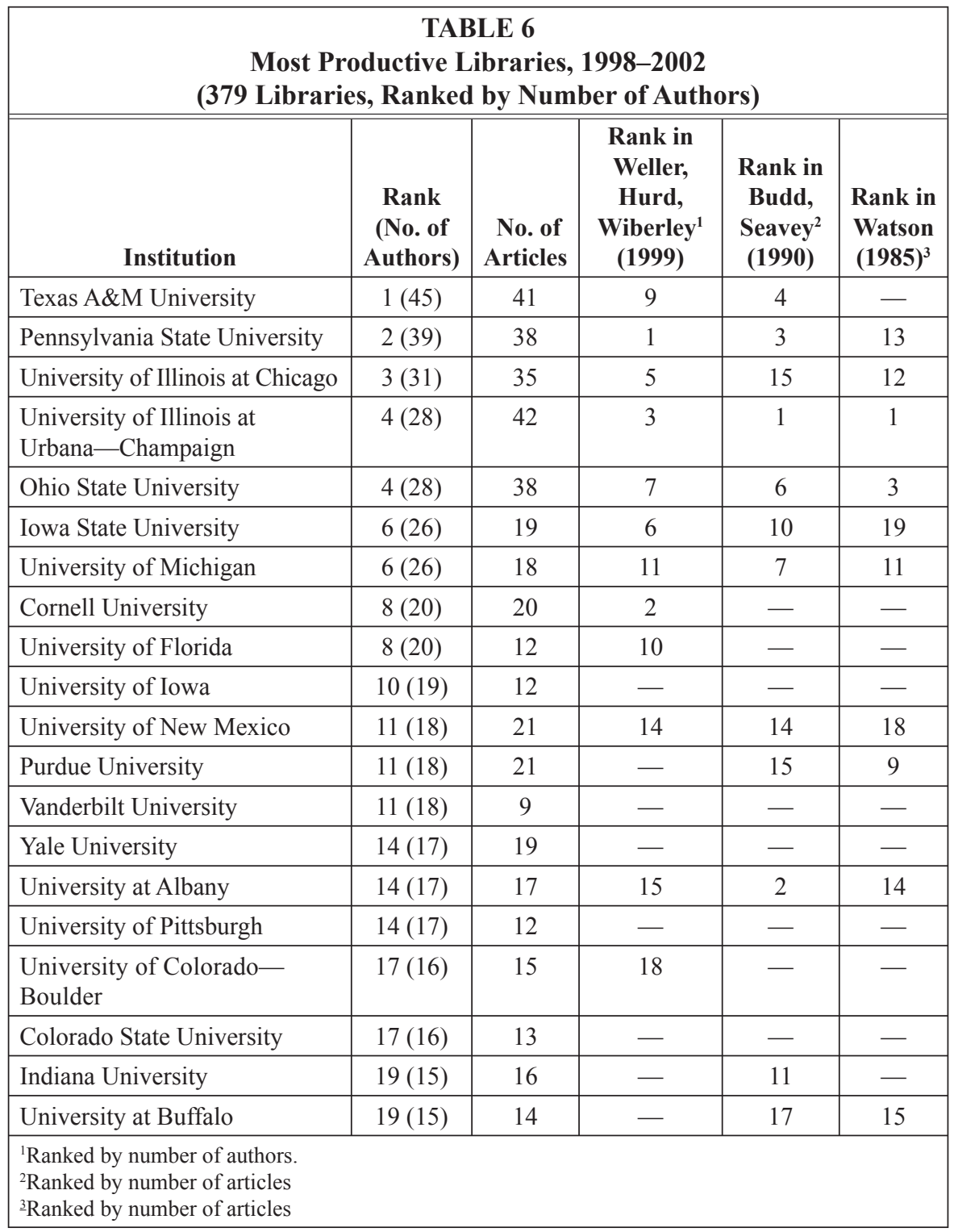

by academic librarians. ${ }^{12}$ For $1993-1997$, the average number of professionals in ARL libraries was 83.8; for 1998-2002, 89.7 , an increase of about 7 percent. ${ }^{13}$

Most studies of LIS journals show that academic librarians outnumber any other type of author. LIS faculty rank second overall, followed by practitioners from other types of libraries. ${ }^{14}$ Between 1993 and 1997, the reported number of LIS fac- ulty was nearly stable. Between 1998 and 2002 , the number rose. Taking the middle years of each period - 1995 and 2000-as the points of comparison, the number of faculty went up about 11 percent, from about 610 to about $680 .{ }^{15}$ Regarding practitioners outside academic libraries, the best data available are for public librarians. Those data show that in 1995 there were 26,636 ALA-MLS public librarians 
and in 2000, 29,519, an increase of about 11 percent. ${ }^{16}$ Taken together, these data show the number of academic librarians, LIS faculty, and public librarians rose roughly from 11 to 16 percent, whereas professionals at ARL libraries rose less (7\%). Given the key role in LIS publishing of librarians at research libraries, the lower growth in their numbers may help explain the smaller proportion of articles and authors from academic libraries. What is difficult to determine is why the overall growth in the number of potential authors did not lead to an increase in refereed articles in the journals studied or a rise in the number of journals in the field.

Another factor related to publication by academic librarians in the studied journals deserves attention. It is possible that just one or two journals could have affected the patterns found. Significant in this regard is the launching in 2001 of portal: Libraries and the Academy. Leaders in academic librarianship developed portal as an alternative to commercially published journals. ${ }^{17}$ In 2001 and 2002, portal published sixty-six refereed articles by ninety academic librarians. Although such output is not sufficient to explain the entire decline of 199 refereed articles by academic librarians between 1993-1997 and 1998-2002, it does constitute about one-third of the gap.

A final way to look at the proportion of contributions of academic librarians is in relation to other studies of the proportion of their contribution to the field's literature. Studies of groups of LIS journals have investigated different combinations of titles. These studies have included some journals with articles that were not refereed. Because the groups of journals varied, one must be cautious about comparisons over time. Nevertheless, it is noteworthy that the proportions of academic librarian authors in these group studies fall within a fairly narrow range-between 26 and 44 percent of the authors were academic librarians. These include Krause \& Sieburth's study of twelve journals, 1973-1982 (approxi- mately $34 \%$ of authors were academic librarians), Watson's study of eleven journals, 1979-1983 (44\%), Buttlar's study of sixteen journals, 1987-June 1989, (38\%), Raptis's study of five journals, 1988-June 1990 (26\%), and Fisher's study of six journals, 1993 (38\%). ${ }^{18}$ The roughly 34 percent found in the present study is about in the middle of the range. The fluctuations in the proportion of academic librarian authors over time reminds us that the decline in their contribution of articles from 1993-1997 to 1998-2002 may be momentary and reverse after 2002. A replication of the present article for journals published 2003-2008 will help ascertain whether the decline found for 1998-2002 marks the start of a downward trend or is a temporary drop.

\section{Patterns of Coauthorship}

Coauthorship is an important characteristic of the literature of a discipline. In general, coauthorship has increased notably in LIS since the 1970s. James L. Terry's study of College $\mathcal{E}$ Research Libraries in fiveyear intervals from 1939 to 1994 shows how that leading journal strongly exemplifies the trend toward greater collaboration. ${ }^{19}$ Although the overall trend is clear, successive volumes of a given journal do not always have a greater proportion of coauthored articles nor do all journals fit the trend. For example, Bahr and Zemon show that in 1995 and 1996, coauthorship in the Journal of Academic Librarianship fell to 40 percent from greater than 60 percent in 1993-1994..$^{20}$ And Hart found continued decline to about 29 percent in 1997-1998. ${ }^{21}$ Some journals have consistently low rates of coauthorship. For instance, Libraries $\mathcal{E}$ Culture and its predecessor, Journal of Library History, have had about a 5 percent rate of coauthorship throughout their history. ${ }^{22}$ In contrast, Journal of the American Society for Information Science had a great increase of coauthored articles from less than 30 percent in the 1950 s to over 50 percent in the 1990s. ${ }^{23}$

Among the thirty-two journals analyzed in the authors' 1999 article and by 
the present study, the proportion of refereed articles with two or more authors declined slightly from 44.97 percent in 1993-1997 to 41.09 percent in 1998-2002. (If one factors in data from JILDDIS and Medical Reference Services Quarterly, the proportion of coauthored articles by academic librarians is $40.93 \%$.) In the thirty-two journals, articles by two authors dropped from 36.35 to 28.62 percent, but articles by three or more authors rose from 8.62 to 12.47 percent.

In addition to the two articles by the authors of the present study, three articles have reported coauthorship rates for groups of LIS journals. Buttlar found a rate of approximately 28 percent in sixteen journals, published in 1987 through June 1989; Raptis found a 14 percent rate in five journals published in 1989 through June 1990; and Fisher found a coauthorship rate of 31 percent in six journals published in $1993 .{ }^{24}$ Seen in the context of those studies, the 41.09 percent of the present article is above the historic range. Perhaps one can attribute the higher percentage to the present study's restriction to refereed articles. Hart reported that for nonrefereed articles written by librarians at Pennsylvania State University, the rate of coauthorship was slightly more than 10 percent, but over 30 percent for refereed articles. ${ }^{25}$ As with the proportion of articles by academic authors, time will tell whether the decline in coauthorship between the present study and the authors' previous study marks the start of a downward trend or is a temporary drop.

Compared to patterns of collaboration found by the authors' 1999 article, the present study showed a greater proportion of coauthorship with librarians from other academic institutions (104 of 567, or $18.34 \%$, versus 81 of 710 , or $11.40 \%$ ) (tables 2 and 5). Two possibilities for this rise are increased mobility and collaboration resulting from grant funding. Increased mobility means that collaborative studies begun by colleagues at one institution did not reach publication until one of the coauthors had relocated and the journal's author description noted the new position. Grant funding may both inspire and enable interinstitutional projects.

\section{Institutional Leaders in Publication}

The present study and the articles by Watson (1985), Budd and Seavey (1990), and the authors (1999) report about highly productive academic libraries. Table 6 records findings of the earlier studies in relation to top-ranked institutions identified by the present study. The twenty most productive libraries published more than 10 percent of all refereed articles and nearly one-third of the articles by academic librarians (tables 2 and 6). Eight libraries have been highly ranked in all four studies, three libraries in three studies, and another four in two studies. The eight libraries that have the most consistent records of substantial publication produced almost 7 percent of all 3,488 refereed articles in the thirty-two journals covered by the present study. Each of these highly productive institutions makes a contribution to the LIS literature that compares favorably to all but the most productive LIS schools. ${ }^{26}$

It is easy to think of LIS schools, especially those in research universities, as having research and publication as part of their missions. What is apparently not so easy is thinking that some libraries have research and publication as part of their missions. Of the eight libraries with long histories of significant publication, only one includes as part of its mission research and publication. ${ }^{27}$ It is fortunate for LIS that the other seven have persisted in making major contributions without public commitment to their efforts. In a time of rapid change in information technology, there is great need for LIS research and the field can ill afford to lose almost 7 percent of the refereed articles in well-recognized journals.

\section{Conclusion}

The present study found that between 1998 and 2002 in the thirty-two journals analyzed, academic librarians produced 
roughly 40 percent of the refereed articles. This proportion is below the almost 44 percent the authors found for the same group of journals between 1993 and 1997. As was true in the authors' previous study, any academic librarian who publishes three refereed articles in a fiveyear period is among the top 10 percent in productivity among academic librarians. Sole authorship is still the norm among academic librarians, although, with 41 percent of articles by academic librarians coauthored, a substantial proportion collaborates. Libraries in research extensive universities continue to dominate the ranks of the most productive institutions. Rankings from the present study suggest that several libraries have a strong tradition of research and publication. Eight have ranked highly since Watson's study of 1985.

As Joswick points out, studies such as the present one and those that cover significant segments of scholars and of publications in LIS tell us about different aspects of the state of the field at particular periods of time. ${ }^{28}$ Combinations of similar studies - for academic libraries, the present one, the authors' 1999 study, Budd and Seavey (1990), and Watson (1985), and for LIS faculty, the series of articles by Hayes (1983), Budd and Seavey (1996), and Budd (2000) - provide indicators of trends. To compete in the marketplace of disciplines, relatively small and comparatively young fields such as LIS need knowledge of themselves and of their standards more than do older fields such as chemistry and history that the general public as well as academics understand better. Numbers of articles published, rates of publication by individuals, productivity by different institutions, and contributions of different groups of authors are important for the evaluation of individual academic librarians and the assessment of particular academic libraries. They also are measures of the health and strength of LIS.

\section{Notes}

1. Robert M. Solow et al., Making the Humanities Count: The Importance of Data (Cambridge, Mass.: American Academy of Arts \& Sciences, 2002), 38, 42-46.

2. John M. Budd, "Scholarly Productivity of U.S. LIS Faculty: An Update," Library Quarterly 70 (Apr. 2000): 230-45; John M. Budd and Charles A. Seavey, "Productivity of U.S. Library and Information Science Faculty: The Hayes Study Revisited," Library Quarterly 66 (Jan. 1996): 1-20; Robert M. Hayes, "Citation Statistics as a Measure of Faculty Research Productivity," Journal of Education for Librarianship 23 (Winter 1983): 151-71.

3. Ann C. Weller, Julie M. Hurd, and Stephen E. Wiberley Jr., "Publication Patterns of U.S. Academic Librarians from 1993 to 1997," College E Research Libraries 60 (July 1999): 352-62.

4. Budd and Seavey, "Characteristics of Journal Authorship by Academic Librarians," College $\mathcal{E}$ Research Libraries 51 (Sept. 1990): 463-70; Paula D. Watson, "Production of Scholarly Articles by Academic Librarians and Library School Faculty," College \& Research Libraries 46 (July 1985): 334-42.

5. Deborah B. Henry and Tina M. Neville, "Research, Publication, and Service Patterns of Florida Academic Librarians," Journal of Academic Librarianship 30 (Nov. 2004): 443.

6. Budd, "Scholarly Productivity of U.S. LIS Faculty."

7. Alice Harrison Bahr and Mickey Zemon, "Collaborative Authorship in the Journal Literature: Perspectives for Academic Librarians Who Wish to Publish, College E Research Libraries 61 (Sept. 2000): 410-19; Gregory A. Crawford, "The Research Literature of Academic Librarianship: A Comparison of College E Research Libraries and Journal of Academic Librarianship," College E Research Libraries 60 (May 1999): 224-30; Edward A. Goedeken, "What We Wrote About and Who We Were: Historical Writings in JLH/LEC, 1966-2000," Libraries and Culture 38 (Summer 2003): 250-65; Richard L. Hart, "Collaborative Publication by University Librarians: An Exploratory Study," Journal of Academic Librarianship 26 (Mar. 2000): 94-99; _—_ "Co-authorship in the Academic Library Literature: A Survey of Attitudes and Behaviors," Journal of Academic Librarianship 26 (Sept. 2000): 339-45; Kathleen E. Joswick, "Article Publication Patterns of Academic Librarians: An Illinois Case Study," College E Research Libraries 60 (July 1999): 340-49; Wallace Koehler, "Information Science as 'Little Science': The Implications of a Bibliometric Analysis of the Journal of the American Society for Information Science," Scientometrics 51, no. 1 (Apr. 2001): 117-32; Ben-Ami Lipetz, "Aspects of 
JASIS Authorship through Five Decades," Journal of the American Society for Information Science 50 (Sept. 1999): 994-1003; Henry and Neville, "Research, Publication, and Service Patterns of Florida Academic Librarians."

8. Budd and Seavey, "Characteristics of Journal Authorship by Academic Librarians"; Mary T. Kim, "Ranking of Journals in Library and Information Science: A Comparison of Perceptual and Citation-based Measures," College E Research Libraries 52 (Jan. 1991): 24-37; Barbara J. Via, "Publishing in the Journal Literature of Library and Information Science: A Survey of Manuscript Review Processes and Acceptance," College \& Research Libraries 57 (July 1996): 365-76.

9. Weller, Hurd, and Wiberley, "Publication Patterns of U.S. Academic Librarians from 1993 to $1997, " 354-56$.

10. Available online from http://www.carnegiefoundation.org/Classification/CIHE2000/ PartIfiles/DRU-EXT.htm. [Accessed 26 September 2005].

11. National Center for Education Statistics, Academic Libraries: 1994, p. iv at http://nces. ed.gov/pubs98/98275.pdf; Academic Libraries: 1996, p. 4 at http://nces.ed.gov/pubs2000/2000326.pdf ; Academic Libraries: 1998, p. 8 at http://nces.ed.gov/pubs2001/2001341.pdf; and Academic Libraries: 2000, p. 2 at http://nces.ed.gov/pubs2004/2004317.pdf. [Accessed 29 September 2005].

12. Mickey Zemon and Alice Harrison Bahr, "An Analysis of Articles by College Librarians," College \& Research Libraries 59 (Sept. 1998): 422-23, 426; Joswick, “Article Publication Patterns of Academic Librarians," 346, 348.

13. ARL Statistics, Summary Statistics. Available online from http://fisher.lib.virginia.edu/cgilocal/arlbin/arl.cgi?task=setupstats. [Accessed 26 September 2005].

14. Thomas E. Nisonger, "Authorship in Library Acquisitions: Practice \& Theory: 1977-1995," Library Acquisitions Practice \& Theory 20, no. 4 (Winter 1996): 406-407; Watson, "Production of Scholarly Articles by Academic Librarians and Library School Faculty," 336; Lois Buttlar, "Analyzing the Library Periodical Literature: Content and Authorship," College \& Research Libraries 52 (Jan. 1991): 43; Paschalis Raptis, "Authorship Characteristics in Five International Library Science Journals," Libri 42, no. 1 (Jan.-Mar. 1992): 41; William Fisher, "When Write Is Wrong: Is All Our Professional Literature on the Same Page?" Library Collections, Acquisitions, and Technical Services 23, no. 1 (Spring 1999): 69.

15. ALISE, Library and Information Science Education Statistical Report 2003, Table I-1. Available online from http://ils.unc.edu/ALISE/2003/Faculty/Table\%20I-1.htm. [Accessed 27 September 2005].

16. National Center for Education Statistics, Public Libraries in the United States: FY 1995, Table 8A at http://nces.ed.gov/pubs98/98301.pdf; and Public Libraries in the United States Fiscal Year 2000, Table 10A at http://nces.ed.gov/pubs2002/2002344.pdf. [Accessed 28 September 2005].

17. Gloriana St. Clair, "Through portal," portal: Libraries and the Academy 1 (Jan.

2001): v-vii. 1

18. Sylvia C. Krausse and Janice Sieburth, "Patterns of Authorship in Library Journals by Academic Librarians," The Serials Librarian 9 (Spring 1985): 127-38; Watson, "Production of Scholarly Articles by Academic Librarians and Library School Faculty," 336; Buttlar, "Analyzing the Library Periodical Literature," 43; Raptis, "Authorship Characteristics in Five International Library Science Journals," 41-42; Fisher, "When Write Is Wrong," 69.

19. James L. Terry, "Authorship in College \& Research Libraries Revisited: Gender, Institutional Affiliations, Collaboration," College \& Research Libraries 57 (July 1996): 377-83.

20. Bahr and Zemon, "Collaborative Authorship in the Journal Literature," 414.

21. Hart, "Co-authorship in the Academic Library Literature," 341.

22. Goedeken, "What We Wrote About and Who We Were," 259.

23. Lipetz, "Aspects of JASIS Authorship through Five Decades," 996.

24. Buttlar, "Analyzing the Library Periodical Literature," 41; Raptis, "Authorship Characteristics in Five International Library Science Journals," 40; Fisher, "When Write Is Wrong," 68.

25. Hart, "Collaborative Publication by University Librarians," 97.

26. Budd, "Scholarly Productivity of U.S. LIS Faculty," 238.

27. http://www.libraries.psu.edu/pubinfo/stratplan2005/\#mission (Penn State); http://www. uic.edu/depts/lib/about/libmission.shtml (University of Illinois at Chicago); http://library.osu. edu/sites/about/index.html (Ohio State); http://www.library.uiuc.edu/committee/strategicplanning/reports/jan00report.htm\#Mission (University of Illinois at Urbana-Champaign); http://www. lib.iastate.edu/libinfo/reptempl/stratplan2000.pdf (Iowa State); http://www.lib.umich.edu/libadmin/mission.html (University of Michigan); University of New Mexico, University Libraries, “University Libraries, Strategic Plan with Implementation Priorities, Updated July, 2004," p. 1 linked from http://elibrary.unm.edu/deansoffice/index.html; http://library.albany.edu/about/mission.htm (University at Albany). [Accessed 13-27 September 2005].

28. Joswick, "Article Publication Patterns of Academic Librarians," 340. 